\title{
Meningkatkan Keterampilan Pukulan Drive dalam Permainan Bulutangkis dengan perbaikan kekuatan gengaman tangan
}

\author{
Dr.Donie, S.Pd, M.Pd \\ donie.fik.unp@gmail.com
}

\begin{abstract}
Abstraks: Penelitian ini merupakan penelitian kuantitatif dengan menggunakan pendekatan korelasi yang bertujuan untuk mengungkapkan hubungan antara kekuatan pegangan tangan terhadap keterampilan pukulan Drive dalam permainan Bulutangkis . Penelitian ini dilakukan pada atlet junior Sumatera Barat dengan jumlah populasi 172 orang, pengambilan sampel dilakukan dengan teknik sampling purposive yang menghasilkan sampel sebanyak 45 orang. Teknik pengumpulan data yang digunakan dalam penelitian ini adalah tes keterampilan dan kemampuan. Untuk melihat kekuatan pegangan tangan dengan menggunakan Grip Strength Dynamometer, sedangkan untuk melihat keterampilan pukulan Drive dalam permainan bulutangkis Bulutangkis menggunakan Wall Volley yang telah dimodifikasi . Hasil penelitian menunjukkan bahwa ada hubungan yang signifikan antara variabel kekuatan pegangan tangan dengan variabel skill strike drive. dalam olahraga Bulutangkis, dan jumlah sumbangannya sekitar $19,7 \%$.
\end{abstract}

Kata kunci: genggaman tangan, pukulan drive, bulutangkis

\section{PENDAHULUAN}

Keberhasilan Susi Susanti dan Alan Budi Kusuma pada cabang bulutangkis yang dapat mengawinkan dua medali Emas Olimpiade di Barcelona Spanyol tahun 1992 menjadi suatu tonggak sejarah momentum olahraga nasional. Keberhasilan tersebut membuat Indonesia sejajar dengan negara-negara peraih medali lainnya seperti Amerika Serikat, Rusia, China dan lain sebagainya dalam prestasi keolahragaan, khususnya bulutangkis.

Dewasa ini kecenderungan untuk bermain dengan speed dan power sepertinya telah meggejala dan menjadi ciri khas permainan bulutangkis moderen, yang ditandai dengan tidak begitu lamanya rally-rally dilakukan, dengan tempo permainan yang tinggi dan pemain cenderung lebih agresif untuk menyerang. 
Tidaklah mengherankan apabila terlihat baik permainan tunggal apalagi permainan ganda para pemain akan saling adu kecepatan untuk saling mendahului untuk menyerang sehingga sering terlihat banyaknya pukulan-pukulan mendatar dan cepat, baik posisi lurus ataupun posisi silang yang dalam bulutangkis dikenal dengan pukulan drive.

Drive yang baik akan dapat memaksa lawan untuk mengangkat bola dan berada pada posisi bertahan, apalagi jika dilakukan dengan kecepatan dan ketepatan tinggi yang mengakibatkan semakin tipisnya dan cepatnya bola melewati net.

Drive yang baik memungkinkan seseorang untuk berada posisi yang tidak tertekan oleh lawan, bahkan drive yang baik cukup efektif menjadi sebuah rangkaian serangan yang dapat mematikan jika dilakukan dengan tepat disertai kecepatan pukulan yang tinggi. Ini sejalan dengan filosofi permainan ganda itu sendiri, dimana "pertahanan terbaik adalah menyerang", maka keterampilan melakukan pukulan drive menjadi suatu keharusan yang wajib dikuasai. Hal ini senada yang dikatakan (Jianyu Wang, 2012) mengatakan bahwa drive adalah pukulan standar yang harus dikuasasi selain pukulan clear, drop dan smash.

Satu hal yang tidak boleh terlupakan bahwa permainan bulutangkis baik tunggal maupun ganda, selain didukung oleh teknik pukulan yang prima, namun harus juga ditunjang dengan kondisi fisik yang baik. Tidak hanya kekuatan dan kecepatan kaki yang membawa tubuh kearah datangnya bola tetapi juga kekuatan dan kecepatan otot-otot tangan baik pergelangan maupun genggaman tangan itu sendiri guna menghasilkan pukulan yang diinginkan secara cepat, kuat dan akurat. Kesemuanya harus menjadi suatu rangkaian gerak yang harmonis dan terkoordinasi dengan baik sehingga akan tercipta permainan bulutangkis yang efektif dan efisien.

Dalam sebuah hasil penelitian “ Mixed Doubles Match Technical and "Tactical Analysis of World Badminton Champion Based on Mathematical Statistics" (Bing Zhang, 2013) menyebutkan bahwa teknik pukulan mendorong tersebut merupakan komponen penting diantara pukulan pukulan lainnya selain service, smash lompat dan lob bersih. Khususnya pada nomor ganda campuran. 
Hasil pengamatan lapangan yang dilakukan selama ini, secara kualitas fisik maupun teknik permainan pasangan ganda Sumatera Barat tidak berada di bawah permainan ganda-ganda dari Pulau Jawa, namun sering kesulitan jika bermain dengan bola-bola cepat dengan tempo yang tinggi. Salah satu penyebabnya adalah masih lemahnya kemampuan melakukan pukulan drive, baik secara kualitas termasuk didalamnya adalah variasi, kekuatan, kecepatan, ketepatan maupun dayatahan untuk mampu memainkan pukulan drive itu sendiri dalam tempo yang tetap tinggi.

Mengingat begitu banyaknya variabel yang ikut mempengaruhi keterampilan pada pukulan drive pada permainan bulutangkis, dan karena keterbatasan dari peneliti sendiri, maka penelitian ini dibatasi pada masalah yang berkaitan dengan kekuatan genggaman tangan serta keterampilan pukulan drive pada permainan bulutangkis.

Bertitik tolak dari latar belakang masalah, identifikasi masalah dan pembatasan masalah di atas, maka dapat dikemukakan rumusan masalah adalah "apakah terdapat hubungan antara kekuatan genggaman tangan dengan keterampilan pukulan drive pada permainan bulutangkis?. Selanjutnya penelitian ini juga diharapkan mampu untuk mengungkapkan hubungan antara: Kekuatan genggaman tangan dengan keterampilan pukulan drive pada permainan bulutangkis.

Salah satu faktor yang mendukung kekuatan genggaman tangan tersebut adalah kekuatan dari otot-otot jari tangan yang tidak hanya memberikan pengaruh terhadap kekuatan genggaman tangan itu sendiri, tetapi juga dapat dijadikan sebagai kontrol terutama terhadap ketepatan suatu pukulan. Hal ini senada dengan hal yang dikemukan oleh PBSI (1985:65) bahwa:

"... dalam pembahasan tentang cara memegang raket perlu dikemukakan disini bahwa keberhasilan pukulan bukan saja ditentukan oleh ayunan tangan dan pergerakan pergelangan tangan tetapi juga oleh kekuatan otot-otot jari... Di dalam melakukan pukulan backhand fungsi jari teramat penting lagi. Pukulan Backhand yang dilakukan tanpa mengfungsikan jarijari tangan tidak akan sempurna arahnya maupun kekuatannya". 
Selanjutnya Kirby dan Roberts (1985:411) mengatakan tujuan utama dari genggaman tangan adalah untuk: (1) meluruskan permukaan raket untuk mendapatkan sudut yang tepat dalam memukul bola, (2) memungkinkan pemain memindahkan semua kekuatan yang dihasilkan dari dalam tubuh kepada bola sesuai dengan arah yang diinginkan.

Drive adalah pukulan yang biasa digunakan untuk menekan lawan atau untuk tidak memberikan kesempatan kepada lawan mendapatkan bola-bola yang melambung sehingga lawan tidak memperoleh kesempatan menyerang dengan pukulan atas. Grice (2002:97) memberikan pengertian drive sebagai pengembalian atau pukulan yang mengarahkan bola dalam lintasan yang relatif datar, sejajar dengan lantai, tetapi dipukul cukup tinggi melewati net.

Tujuan pukulan drive ialah mengirimkan shuttlecock mendatar melewati net sehingga jauh masuk di arena lawan. Drive shot dilakukan dengan pukulan di samping lengan. Baik pukulan lurus maupun drive shot menyilang dapat dilakukan dengan menggunakan backhand atau forehand stroke. Drive paling sering digunakan dalam permainan ganda pria dan ganda campuran. Karena court lebih sempit, drive shot jarang digunakan dalam permainan tunggal (Johnson;1984:96). Pukulan drive yang dilakukan dengan baik juga akan memberikan manfaat dalam mempercepat tempo permainan dengan meluncurkan bola serendah-rendahnya, mengacaukan posisi lawan, menekan lawan/inisiatif menyerang dan pada posisi tertentu bisa menjadi serangan balik yang efektif dan mematikan.

Hal penting yang harus diperhatikan dalam melakukan pukulan drive menurut Sugiarto (2002:64) adalah Pukulan bola dari samping badan pada ketinggian sebatas pinggang. Apabila atlet mengambil bola dari tempat yang lebih rendah, misalnya setinggi lutut, maka pukulan drive akan kehilangan daya serangnya, lagi pula amat mudah dicegat atau ditebas lawan.

\section{METODE}

Penelitian yang dilakukan bersifat kuantitatif dengan pendekatan 
korelasional yang bertujuan untuk melihat bobot ataupun keeratan hubungan antara variabel-variabel yaitu antara variabel kekuatan jari-jari tangan (X) terhadap variabel keterampilan melakukan pukulan drive dalam permainan bulutangkis (variabel terikat Y).

Populasi dalam penelitian ini adalah seluruh atlet junior (16 s/d 22 tahun) Sumatera Barat yang aktif dalam pembinaan prestasi atau latihan pada klub klub tertentu yang mengadakan latihan secara kontiniu dan teratur .

Pengambilan sampel dalam penelitian ini dilakukan dengan menggunakan Teknik Purposive Sampling yaitu teknik yang dipilih secara khusus berdasarkan tujuan penelitian yaitu terhadap jenis kelamin dan usia (Usman dan Akbar :1996)

Teknik Pengumpulan data adalah dengan menggunakan test kemampuan dan tes keterampilan, untuk Kekuatan genggaman tangan adalah (test Kekuatan genggaman tangan dengan menggunakan alat Grip Strength Dynamometer sedangkan untuk test keterampilan pukulan drive pada bulutangkis digunakan Badminton Wall Volley Test yang telah dimodifikasi.

Sebelum dilakukan analisis terhadap hipotesis korelasional yang diajukan, terlebih dahulu dilakukan uji persayaratan analisis seperti: uji normalitas, linearitas dan independensi terhadap variabel (Hadi: 2000: 102).

Pengujian hipotesis antara variabel bebas dengan variabel terikat, menggunakan teknik analisis Product Moment dari Pearson. Apabila signifikan dilanjutkan dengan menggunakan regresi sederhana.

\section{HASIL PENELITIAN DAN PEMBAHASAN}

Penjelasan dari data yang diperoleh dalam penelitian ini didapatkan skor yang tertinggi 47,30 dan skor terendah 31,70, sedangkan distribusi skor menghasilkan rata-rata (mean) 40,19, simpangan baku (standard deviation) 4,08, skor tengah (median) 40,80, skor yang banyak muncul (mode) 42,30, variansi (variance) 16,68 dan jarak pengukuran (range) 15,60.

Selanjutnya sebelum dilakukan analisis terhadap hipotesis korelasional yang diajukan, terlebih dahulu dilakukan uji persyaratan analisis seperti uji normalitas dan linearitas dengan hasil terdapat pada rangkuman table 
sebagi berikut:

Tabel . Rangkuman Uji Normafitas Kelompok Sampel Penelitian Atlet Bulutangkis

\begin{tabular}{|c|c|c|c|l|}
\hline NO & Variabel & \multicolumn{2}{|c|}{$\begin{array}{c}\text { Sig > Alpha } \\
\mathbf{0 . 0 5}\end{array}$} & Kesimpulan \\
\hline 1 & Kekuatan Genggaman Tangan (X) & 0.495 & 0.05 & Normal \\
\hline
\end{tabular}

Tabel. Rangkuman Uji Lineritas

\begin{tabular}{|c|c|c|c|c|}
\hline $\begin{array}{c}\text { Variabel } \\
\text { Bebas }\end{array}$ & $\begin{array}{c}\text { Variabel } \\
\text { Terikat }\end{array}$ & $\mathbf{F}_{\text {Hitung }}$ & $\begin{array}{l}\mathbf{F}_{\text {tabel }} \\
\boldsymbol{\epsilon = \mathbf { 0 . 0 5 }}\end{array}$ & Kesimpulan \\
\hline $\mathrm{X}_{1}$ & $\mathrm{Y}$ & 1.258 & 5.15 & Linear \\
\hline
\end{tabular}

Untuk melihat menganalisa hubungan antara Kekuatan Genggaman Tangan (X) dengan Keterampilan pukulan Drive pada Permainan Bulutangkis digunakan Analisis korelasi sederhana, hasil menunjukan sebagaimana terlihat pada tabel berikut ini:

Tabel Rangkuman Uji Keberartian Koefisien Korelasi antara Variabel Kekuatan Genggaman tangan (X) dengan Keterampilan Pukulan Drive Pada Permainan Bulutangkis (Y)

\begin{tabular}{|r|c|c|c|l|}
\hline $\begin{array}{c}\text { Koefisien } \\
\text { Korelasi (r) }\end{array}$ & $\begin{array}{c}\text { Koefisien } \\
\text { Determinasi }\end{array}$ & $\mathbf{t}_{\text {hitung }}$ & $\begin{array}{c}\mathbf{t}_{\text {hitung }} \boldsymbol{\alpha} \\
\mathbf{= 0 , 0 5}\end{array}$ & Keterangan \\
\hline 0,444 & 0,197 & 3,25 & 2,01 & Signifikan \\
\hline
\end{tabular}

Dilihat dari table tersebut ternyata terdapat hubungan yang berarti. antara Kekuatan Genggaman Tangan (X) dengan Keterampilan Pukulan Drive pada 
Permainan Bulutangkis (Y)

Untuk melihat kontribusi atau sumbangan variabel Kekuatan Genggaman Tangan (X) terhadap Keterampilan Pukulan Drive pada Permainan Bulutangkis diperoleh indeks koefisien determinasi $(\mathrm{r} 2)=0,197$. Dengan demikian Variabel Kekuatan Genggaman tangan berkontribusi terhadap Keterampilan Pukulan Drive pada Permainan Bulutangkis sebesar 19,7\% (0,197 x 100\%), sisanya 80,3\% diduga dipengaruhi oleh variabel lain.

Setelah terbukti hipotesis pertama diterima, dilanjutkan dengan dengan analisis uji keberartian persamaan regresi (uji F) dengan hasil sebagai berikut:

Tabel. Rangkuman Analisis Uji F dan Persamaan Regresi

Variabel Kekuatan Genggaman Tangan (X) dengan

Keterampilan Pukulan Drive pada Permainan

Bulutangkis (Y)

\begin{tabular}{|c|c|c|c|c|c|}
\hline \multirow{2}{*}{ Variabel } & \multirow{2}{*}{ Fhitung } & Ftabel & Keterangan & $\begin{array}{c}\text { Kekuatan } \\
\text { Genggaman } \\
(0.05)\end{array}$ & Konstan \\
\cline { 4 - 6 } & & 3.32 & Signifikan & 1.013 & 81.239 \\
\hline $\begin{array}{l}\text { Kekuatan Genggaman } \\
\text { Tangan (X) dengan } \\
\begin{array}{l}\text { Keterampilan Pukulan } \\
\text { Drive pada Permainan } \\
\text { Bulutangkis (Y) }\end{array}\end{array}$ & 10.561 & & & \\
\hline
\end{tabular}

Berdasarkan Tabel di atas ternyata Uji F diperoleh nilai Fhitung > dari Ftabel, maka konsekuensinya adalah persamaan garis regresi signifikan dan dapat digunakan sebagai alat prediksi untuk melihat gejala hubungan dalam penelitian ini.

Berdasarkan Tabel tersebut juga diperoleh harga beta konstan (a) 81,239 dan harga beta X, (b) adalah 1,013, maka persamaan garis regresi antara kekuatan genggaman tangan dengan keterampilan pukulan drive pada permainan bulutangkis dapat disusun sebagai berikut:

$$
\mathrm{Y}=81,239+1,013 \mathrm{X}
$$


Hal ini berarti bahwa walaupun terdapat hubungan yang positif dan signifikan antara kekuatan genggaman tangan dengan keterampilan pukulan drive pada permainan bulutangkis, namun pengaruhnya masih sedikit sekali. Selain banyaknya variabel lain yang turut mempengaruhi, dalam hal kekuatan genggaman tangan ini juga masih terbatas pada kekuatan genggaman statis.

Walau tidak memberikan pengaruh yang besar terhadap keterampilan pukulan drive pada permainan bulutangkis, namun salah satu manfaat terbesar dari pada kekuatan genggaman tangan tersebut antara lain untuk meluruskan permukaan raket untuk mendapatlkan sudut yang tepat dalam memukul bola dan untuk memindahkan semua kekuatan yang dihasilkan dari dalam tubuh kepada bola sesual dengan arah yang diiginkan (Kirby dan Roberts: 1985 :114).

Artinya kekuatan genggaman tangan berperan juga sebagai kontrol ataupun kendali, baik itu untuk mendapatkan sudut yang tepat dalam memukul bola, juga sebagai kontrol dalam memindahkan semua kekuatan yang dihasilkan dari dalam tubuh guna mendapatkan sasaran yang diinginkan. Kemudian bentuk Persamaan Regresi dinyatakan dalam persamaan regresi linear sebagai berikut:

$$
\mathrm{Y}=81,239+1,013 \mathrm{X}
$$

Persamaan regresi yang telah ditemukan dapat digunakan untuk melakukan prediksi (estimasi) bagaimana pengaruh variabel independen terhadap besarnya perubahan variabel dependen. Misalnya kekuatan genggaman tangan yang diberikan sebesar 30, maka nilai keterampilan pukulan drive pada permainan bulutangkis adalah seperti persamaan di bawah ini: $Y=81,239+1,013 \times 30$ $=111,269$

Jadi estimasi niiai keterampilan pukulan drive sebesar 111,269 dengan penambahan kekuatan genggaman tangan 30. Persamaan regresi di atas dapat diartikan bahwa kekuatan genggaman tangan bertambah 1, maka nilai rata-rata keterampilan pukulan drive pada permainan bulutangkis bertambah 1,013 atau setiap nilai kekuatan genggaman tangan bertambah 10 dan nilai rata-rata keterampilan drive pada permainan bulutangkis bertambah sebesar 10,13.

\section{Kesimpulan dan Saran}


Penelitian mengenai Hubungan Antara Kekuatan Genggaman Tangan Dengan Keterampilan Pukulan Drive dalam Permainan Bulutangkis telah dilakukan melalui tahapan tahapan yang merupakan aturan ataupun ketentuan yang lazim dilaksanakan dalam penelitian kuantitatif yang meliputi: pemilihan instrumen, pengujian insrumen, melaksanakan pengumpulan data sampai akhirnya penarikan kesimpulan.

Berdasarkan hasil penelitian, dapat diperoleh kesimpulan bahwa Kekuatan genggaman tangan mempunyai hubungan yang berarti atau signifikan dengan keterampilan pukulan drive pada permainan bulutangkis, walaupun hanya memberikan sumbangan yang tidak terlalu besar hanya 19,7\% namun dapat digunakan untuk memprediksi dalam peningkatan keterampilan pukulan drive pada permainan bulutangkis. Artinya, jika kekuatan genggaman tangan tersebut ditingkatkan, maka ada kecenderungan keterampilan pukulan drive pada permainan bulutangkis akan meningkat pula.

\section{DAFTAR PUSTAKA}

Bing Zhang, F. L. (2013). Mixed Doubles Match Technical and Tactical Analysis of World Badminton Champion Based on Mathematical Statistics. Advances in Physical Education, 154-157.

Grice, Tony. (2002). Bulutangkis Petunjuk Praktis Untuk Pemula dan Lanjut. Jakarta: PT. Rajagrafindo Persada.

Hadi, Sutrisno. (2000). Seri Program Statistik-Versi 2000. Yogyakarta: Universitas Gadjah Mada.

Johnson.(1984). Bimbingan Bermain Bulutangkis. Jakarta: Mutiara Sumber Widya

Jianyu Wang, W. L. (2012). Changes in Badminton Game Play across Developmental Skill levels among High School Studen. Teaching in Physical Education, 29-37.

Kirby, Ronald and Roberts John A.(1985). Introductory Biomechanics. New York: Movement Publications, Inc. 
Persatuan Bulutangkis Seluruh Indonesia. (1985). Pola Pembinaan Bulutangkis Nasional Bagian B. Jakarta: PB. PBSI.

Sugiarto, Icuk. (2002). Total Badminton . Jakarta: CV. Setyaki Eka Anugerah 